\title{
Strangers at home: narratives of northern Muslim returnees in post-war Sri Lanka
}

\author{
Diotima Chattoraj $^{1^{*}}$ and Eva Gerharz ${ }^{2}$ \\ ${ }^{1}$ University of Brunei, Darussalam, Brunei. \\ ${ }^{2}$ Fulda University of Applied Sciences, Germany.
}

\begin{abstract}
This article focuses on the experiences, aspirations and challenges of Sri Lankan Muslim returnees to northern part of Sri Lanka in Jaffna and analyses their strategies to cope with the ambivalent situation thereafter. The empirical point of departure is drawn from the stories of three Muslim returnees in Jaffna who returned from different parts of Sri Lanka. The article finds that the Muslim returnees conceptualise home as a place where they can have a "better future" than the displaced location where they stayed for so long. The authors argue that this unveils the different kinds of attachment they have to their homes through memories, emotions and material and immaterial properties. There exists feelings of alienation and detachment from their homes among some. Furthermore, their aspirations of a good life seem to be decaying in their homes after their return.
\end{abstract}

Keywords: Home, return, Muslim returnees, attachment, belonging.

\section{INTRODUCTION}

Sri Lanka experienced 26 years of vicious fighting between the national government and the Liberation Tigers of Tamil Eelam (LTTE), which ended in May 2009 with the military defeat of the LTTE. With the claim to fight for the self-determination of Sri Lankan Tamils, LTTE fought an ever-intensifying battle with the military forces in the north and east of the country, considered by the LTTE as the Tamil Eelam (homeland) (Chattoraj \& Gerharz, 2019). The war witnessed the death of hundreds, displacement of more than a million and destruction of physical and human infrastructures (Chattoraj, 2019).
The Muslims, who formed the second largest minority community, were scattered throughout the northern provinces. Although the LTTE claimed to represent all Tamil-speaking people which also included the Muslim population in the Tamil Eelam, serious differences were observed in the form of increasing political opposition. From the 1980s onwards, the Muslim population explicitly promoted its own political representation based on ethno-religious differences. Over the course of time, the complex relationship between Muslims and Tamils led to an emerging polarisation and also to violent confrontations. A decisive event which devastated inter-ethnic relations took place in 1990, when the LTTE expelled some 75,000 Muslims from the northern province (Chattoraj, 2017). In the following years, the LTTE provided a couple of justifications for this mass expulsion, which resembles an act of ethnic cleansing. Muslim politicians considered the eviction of the Muslim community from the entire province as a political strategy of the LTTE and Tamils to establish a mono-ethnic Tamil state in the region. This expulsion had an impact not only on the demographic composition of that region, but also on other areas: some displaced Muslims moved to Colombo and joined the relatively large Muslim community there, some sought refuge in other parts of Sri Lanka and the majority ended up in refugee camps in Puttalam, the district bordering the territory claimed by the LTTE in the north (van Hear \& Rajasingham-Senanayake, 2006: p. 50). Throughout the war, the displaced Muslims did not dare take the

"Corresponding author (diotima.chattoraj@gmail.com; (iD https://orcid.org/0000-0001-8397-8765)

This article is published under the Creative Commons CC-BY-ND License (http://creativecommons.org/licenses/ by-nd/4.0/). This license permits use, distribution and reproduction, commercial and non-commercial, provided that the original work is properly cited and is not changed anyway. 
possibility of resettlement into account, fearing the incalculable reaction of the LTTE. At the same time, many of them refrained from registering themselves as residents in their new places because of the fear that this might forfeit their right to reclaim their property and resettle in the Northern Province (Haniffa, 2007: p. 52).

Post-2009, Sri Lanka is struggling to find a way to accommodate minority interests within the democratic system. Although various economic reconstruction initiatives have taken place, feelings of having been left out are widespread amongst Muslims, especially in Jaffna. There is a high level of mistrust, reflected in the refusal of most of Internally Displaced People (IDPs) to return to their former homes, because of the traumatic experiences of being repeatedly expelled (Chattoraj \& Gerharz, 2019). Many fear political and socio-economic disadvantage in the north, as they are disproportionally left out of repatriation schemes. Yet, with the end of the war, several thousand returned to their places of origin in Jaffna because of the sense of belonging to their places of origin, signifying the existence of an 'intimate connection' to the place. Returnees also express their obligations towards the people of their homeland in Jaffna with respect to certain duties-which hints at the social dimensions of belonging. Apart from a 'longing' for their places of origin in the physical sense, a connection with the people living there also gets highlighted. The interviews also revealed that these dimensions of belonging were missing in their places of displacement where they spent several years after forced displacement. Thus, this article seeks to raise pertinent questions which might help to develop a deeper understanding of migrants' relationship to their places of origin. To do this, the authors use data which stems from narrative interviews with IDPs who decided to return to their places of origin in the northern peninsula. Based on analysis of the empirical data, this article unravels the different ways in which people relate to a homeland from which they were forcefully displaced. The article concentrates particularly on Muslims who had been evicted from Jaffna, a place known for being the heartland of Tamil nationalism. Investigating their case, which has often been overlooked by most scholars, is particularly insightful because, in their case, 'home' refers mainly to the Muslim neighborhood of Moor Street, located in a semi-urban region of Jaffna town (Ismail \& Azeez, 2014). Although Muslim settlements were found in many areas in the Jaffna peninsula, the majority concentrated in 'Moor Street', a neighborhood comprising various roads and lanes,

“including Azad Road, Mohideen Mosque Lane and Jinnah Lane. Since the early $17^{\text {th }}$ century, Muslims settled in this area, which was said to have had 17 mosques, six government schools and four large Madrasas ${ }^{1}$. The affluent businessmen who lived there had their businesses such as import-export of goods, gold and jewelry and hardware located outside and within Jaffna town. Although this area was a clearly demarcated Muslim quarter with a distinctive way of life, housing, language and cuisine, there was much interaction with the Muslims living outside the area and with the Tamil community" (for further details see Ismail \& Azeez, 2014; pp: 1-4).

Based on a qualitative approach, on which the article is written, this research was guided by a holistic understanding of complex issues and processes and increase the likelihood of uncovering unexpected and sensitive issues that are relevant to the essence of human existence (Cresswell, 2003). A detailed view on how returnees experience returns and relate with their 'home', socially as well as emotionally, emerged from the data that were gradually gathered during fieldwork. Respondents were encouraged to talk about their past lives, their experiences, aspirations and challenges after returning to their places of origin. A total of thirty interviews were conducted, among which three cases were taken up to present in this article. These interviews were conducted with the Muslim returnees in two phases: one in February-March 2013 and the other in 2015. The interviews were in-depth, informal and semi-structured. They were held in Tamil and were translated into English by an interpreter. In-depth, informal and semi-structured interviews with men and women of varying ages were the primary method of data collection. Some of the recent data (those of 2018 and 2019) were collected via phone and email from the informants in Sri Lanka. Respondents were informed well before about the purpose of this work and the methodology, including the nature of questions they would be asked. They were also informed about the group of people who would be having access to the findings of the research and the means of its readings and publication. Each of the respondents had been given the freedom to openly partake and refuse or withdraw participation from the research at any point in time. The authors use pseudonyms and do not reveal private data identifying the subjects (Kvale, 1996: p. 114).

In the main section of this article, different cases will be highlighted which will show that return was inspired by and connected with high expectations, which were soon replaced by a deep sense of disappointment and led the protagonists to reconsider and renegotiate their relationship to the place. The analysis reveals that the emotional attachment to home is structured not only in spatial but also in temporal terms. Memory, as well as future perspectives and aspirations, determine 
the ways in which people relate to their homes. The empirical material shows that for the displaced, return is a necessary step in order to develop the capacity to formulate perspectives and aspirations and to envision the future.

The article is structured as follows: First, the authors will introduce the different notions of home, attachment and return, and reveal how they conceptualise the relationship between these concepts. Second, the Sri Lankan context in general will be introduced along with the situation of Muslims and their relationship to the Tamils, in particular. The authors will also introduce Jaffna as the site where the research has been conducted. In the third part, the narratives of the returnees will be reconstructed. By revealing their stories, the authors attempt to decipher not only their emotional stances and grievances, but also highlight the various and multifaceted ways in which they renegotiate their attachment to the place of origin. In the conclusion, the authors discuss the findings and suggest some lines of enquiry for future research.

\section{HOME, ATTACHMENT AND RETURN: THE CONCEPTS}

With its promise to overcome the fallacies of categorical thinking, the notion of belonging has received much attention recently. It certainly helps to provide a more differentiated understanding of how individuals and collectives construct and experience their position within society, by highlighting that a multiplicity of options exists and defining 'belonging' from both a processual and a relational perspective. However, the notion of belonging also relates to collective positions. In contrast to 'identity', it denotes not only formal membership and labelling but highlights both imagined and narrated constructions related to sameness, unity and togetherness (Pfaff-Czarnecka \& Toffin, 2011). Apart from performances of 'commonality', it points out the ways in which people relate to each other in terms of 'mutuality' as well as material and immaterial 'attachments'. The notion of belonging, thus, enables differentiation between the ways in which people themselves construct belonging to collectives, and to places (such as cities). Membership, as a social property, depends heavily on the ability and willingness of groups to admit a person. Drawing on Pfaff-Czarnecka's (2013: p.13) differentiation between an individual's relations to a collective and collective belonging, the article concentrates on the individual's quest to belong, i.e. 'belonging to' rather than 'belonging together'.

This preoccupation, however, does not prevent the authors from acknowledging that these various dimensions intersect in many ways. Therefore, the three dimensions Pfaff-Czarnecka identifies as analytical, concern themselves with the ways in which people construct their belonging. The first dimension, commonality, refers to collective processes but also relates to how individuals feel and embody 'belonging' in collective constellations. The second one, mutuality, means that individuals acknowledge the other(s) and that this results in a compliance to rules ordering social relations (Pfaff-Czarnecka, 2013: p. 16). However, it is not only about rules and obligations, mutuality also means loyalty and commitment—and thus, is a highly emotional component. The third dimension is the one the authors would like to emphasise in the subsequent sections of this article; attachment. The authors take it to mean a deep and enduring emotional bond connecting individuals across time and space (Ainsworth, 1979; Bowlby, 1998), which links people to material and immaterial worlds (Pfaff-Czarnecka, 2013: p. 17), making them belong to spaces and sites, to natural objects, landscapes, climates and to material possessions (Appadurai, 1986; Hooks, 2009). These kinds of attachments are produced through such diverse devices as embodiment, the resonance of smells and tastes or citizenship and property rights (Pfaff-Czarnecka, 2013: p. 17). However, it is not only the place as such, but also locality in the sense of a social and emotional reference point that provides the basis for such attachment.

In the context of attachment to 'home' about the Sri Lankan Tamils, 'home' is their natal village in which they were born and nurtured. It reveals their character which is necessary for social interaction. Moreover, persons belonging to the same 'home' share similar characteristics through their "nourishment in the same soil" providing "collective identification of people from that "home"" (Thiranagama, 2011: p. 18). They consider staying away from their 'home' as a form of supreme punishment which is much more severe compared to the death penalty (Cheran, 2007: p. 151). The Northern Muslims, in this regard, shape their ideas of home through the "historical and political trajectories" as argued by Thiranagama (2011: p. 19). Home, in this context, has been studied as "an everyday language of love, affection, sentiment and memory" (ibid.: p. 19). In his art-book, The Incomplete Thombu, Sanathanan (2011) addressed the varied memories of IDPs in Sri Lanka of their homes which were made up of their kith and kin, neighbors, objects, events, plants and smells. In addition to this, as Chattoraj (2017) has shown, the Northern Muslims consider memories (both good and broken), people (family and neighbors) and ambiance (safety and security) as the main elements of home-making.

In the context of internal displacement, attachments to 'home' bear a unique quality which witness people 
who unwillingly left their places of origin and their belongings, and whose state of being, as stated by Chattoraj (2018: p. 139), has been characterised by an additional loss in social terms. The idea of home is emotionally highly-charged, and 'return' not only means to reacquire what has been lost but also carries with it a feeling of relief with an end to uncertainty, insecurity, fear and terror. As Hammond (1999) states, 'return' means going back to a way of life and an association between a familiar identity and place. Nonetheless, she remains inclined more on return as a 'new beginning' rather than 'return to the past' (Hammond, 1999: p. 229). Complementing this view of Hammond, Chattoraj (2018) also argues that displaced people long for their homes and returning home means to make 'a fresh start' (p. 139). Zetter (1999) notes that refugees think of the past, from which they derive their identity, in a highly romanticised way. Further, the refugee, as stated by Zila (2015), who did not consider returning home as actual and understood it more on the symbolic level (i.e. as an indefinite imaginary desire), made use of it at the same time to idealise his distant future (ibid.: p. 132). Based on this argument, the authors can examine the extent to which refugees link their romanticised memories of the past with the view of an imaginary future, perpetuating the 'myth of return' alive. In the Sri Lankan context, returning home means a fresh start, especially for those who have not been able to acquire a better social status while being displaced. To explain this in the context of Muslim returnees to Jaffna, a deeper look into the history of the war and associated displacements is required, as well as an analysis of recent developments that will help in locating the cases of Muslim returnees.

\section{DISPLACEMENT AND THE NORTHERN MUSLIMS}

The minority Muslim community, comprising of $8 \%$ of the country's 21.02 million population (Sri Lanka, Department of Census and Statistics, 2019), was scattered in significant numbers in the south, and constituted one-third of the population of the Eastern Province and a significant number of them used to be in the north until their expulsion by the LTTE from the northern provinces in October 1990 (Minority Voices Newsroom, 2014). Their main sources of livelihood were agriculture, fishing and businesses (ibid.). They even maintained a close relationship with the Tamils, mutual trust in trade and business and in their cultural practices (Yusoff et al., 2018). However, they were victimised during the ethnic conflict although they had never been a competing or conflicting party. Their mass expulsion from the northern province, by the LTTE, was one of the greatest injustices meted out to them and has been considered as the most cruel and inhumane episode which is synonymous with 'ethnic cleansing'. Since then, they have been going through a vulnerable life. Finally, with the defeat of the LTTE in May 2009, the twenty-five-year war came to an end, killing well over 100,000 people and displacing more than one million (Chattoraj \& Gerharz, 2019). The end of the war created high hopes among this population that their displaced life would come to an end soon and as citizens of Sri Lanka, they have the right to return and resettle in their original homes assisted by the government, politicians and civil forces (Hasbullah, 2004). Continuously neglecting to help them resettle is a denial of their right to live in their own lands (ibid.). Therefore, resettling them along with the displaced Tamils would resolve their grievances and create room for the empowerment of their lives, livelihood and improve relations with the other ethnic groups in the post-war era. Nevertheless, resettling them is also a difficult issue as most of them are wary of leaving their displaced locations because they lack the means to resettle. They have been displaced for more than decades and have built a life in their displaced areas where they opt to integrate. Many have strongly integrated and have established houses and businesses in their displacement locales, and their children, born and brought up in displacement, are comfortable with the available educational and vocational facilities. However, vulnerabilities exist within their community with different aspirations for their return and the complex nature of protracted displacement. Those who do not own property and do not have sustainable livelihoods considered to return to their original homes, whereas the others were reluctant. Literature and the collected data reveal that the lack of proper assistance and basic amenities pose a serious challenge to the resettlement of northern Muslims who have already returned to their original homes (Yusoff et al., 2018; Chattoraj, 2017).

In 2011, several displaced Muslims registered to return to their original homes with the hope that government authorities could make necessary arrangements and facilities, such as identifying and allocating lands for their resettlement, initiating housing projects and expanding livelihood opportunities (Yusoff et al., 2018; Fonseka \& Raheem, 2011). Furthermore, their areas were decimated and their homes were destroyed during their long displacement. Further, families have expanded, and returning Muslims need land, infrastructure and livelihood assistance (Haniffa, 2014). For them, scant information and little discussion exist on their available choices of return or integration. Conditions in return sites are poor and limited assistance means that they require time to rebuild their lives all over again. In addition, the extent of assistance for families who are landless or are 
occupying land without proper documentation (i.e. those families who were born and grew up in displacement and are not able to make any land claims) is unclear (Fonseka \& Raheem, 2011). Several studies and commissioned investigations found that the evicted northern Muslims are in a deplorable position in terms of their displaced status and opportunity to return to their original homes with official sponsorship. As argued, their forceful eviction and the delay of their permanent resettlement are violations of their right to own and live in their own lands. The Lessons Learnt and Reconciliation Commission (LLRC) in its final report (Sri Lanka, Report of the Commission of Inquiry on Lessons Learnt and Reconciliation, 2011) acknowledged that displaced northern Muslims have been living in "dire conditions" for more than two decades and are experiencing trouble integrating and noted that,

"the treatment given to the Muslim community of the northern province has led them to believe that they are at the bottom of the list of priorities of the government, INGOs, NGOs, and the donor community" (IRIN News, 2013).

The same report concluded that displaced Muslim persons remain one of the "key post-conflict challenges" with "significant impact" on reconciliation prospects. The LLRC agreed that durable solutions must be found to address these long-standing issues concerning the evicted northern Muslims, which would sow seeds of disharmony and dissension if they remain unaddressed (IRIN News, 2013).

With the end of the war, several national and local developmental initiatives are being taken, however, neither the northern Tamil political leaders nor the radical nationalist forces within the Sinhalese-Buddhist community made meaningful initiatives to resettle the Muslims in their original homes. Till date, most Tamils remain indifferent to the return of the Muslims, reflecting the weakened Tamil-Muslim relations and a Tamil public sphere where little has been done to rebuild them (Kadirgamar, 2015). Jeyaraj (2015) argued that in an environment where reconciliation is being talked about nationally and globally, the need for rapprochement exists between Tamils and Muslims in the north. Strong and sincere efforts should be made to extend the hand of friendship to this displaced population and support their permanent resettlement. There have been considerable debates among Tamil politicians regarding the eviction of northern Muslims who claimed that the eviction was for the sake of the Muslim community. There are also instances which show the opposition of the Sinhalese nationalists regarding the resettlement of the Muslims at their original homes in Mannar district. The Sinhalese claimed that resettlement in those areas are 'illegal' as they belong to the national wildlife protection area although Muslims held deeds to these lands (Asees, 2015). Moreover, they claimed that Muslims destroy the national forest, nature, the environment and illegally own government land.

In addition, the fragmentation of Muslim politics has also negatively influenced the process of their resettlement. Several new Muslim parties and forces have emerged since 2000, and have been influencing Muslim and national politics. For the resettlement of northern Muslims, most of these parties have done little, except reporting about the anniversary of these Muslims' eviction to the media. In certain parts of the Northern Province, Muslim politicians exploited the situation of the returning population. Further, this fragmented Muslim politics has been considered by the survey respondents to be the main reason of complications regarding their return to their homes. Kadirgamar (2015) rightly pointed out that on the matter of these Muslims' settlement, the politics of patronage led to handouts for some, but the marginalised continued to suffer as they faced what was a mockery in the name of resettlement. Minority Voice Newsroom (2014) argued that the expulsion of these Muslims remained marginal within the discourse of ethnic conflict and the many peace processes due to a combination of factors, namely, the lack of community mobilisation, insufficient attention and failure to obtain recognition at national and international levels through publicising the issue by Muslim politicians. Moreover, the northern Muslims' interests became secondary to the interests of many Muslim political parties.

Unfortunately, the end of the war created no room for the improvement of the vulnerable lives of the Muslims. Since the author's visit to the island in 2013, the Muslims have always been targeted by the forces of SinhalaBuddhist supremacy in their campaigns for ending Halal certification, in the agitations for the boycott of Muslimowned businesses, and above all in the anti-Muslim riots of 2014 and 2018 that resulted in the looting and burning of hundreds of Muslim shops and homes (Arudpragasam, 2019; Chattoraj, 2017). Finally, the $21^{\text {st }}$ April (2019) Easter Sunday bombings by the Islamist group National Thowheed Jamaath $\left(\mathrm{NTJ}^{2}\right)$, drove the nail in their coffins. The outbreaks of violence that followed against the Muslim community thereafter, has been aptly viewed as horrifying. One such impact is the banning of the 'Burqa' and 'Niqab' (types of face cover) of the Muslim women (Hasanah, 2019). Unfortunately, there have been many terrorist attacks across the world killing thousands of civilians. Yet, except for one incident in Yemen where a man in a Burqa possessed weapons, all 
the other attackers were open with their identities. Even in Sri Lanka during incidents of 'Tiger terrorism' by the LTTE, the female suicide bombers never covered their faces with a Burqa or Niqab. Those who were directly involved in this heinous crime should be looked upon as inhuman. They committed the murders, clearly exhibiting their identities, proving that there is no connection between terrorism and the Burqa/Niqab. The fact that the bombings were directed primarily against Christians rather than Buddhists will be taken as evidence by many Sri Lankans that the bombings have their source in Jihadist ideology alone. Whatever motivations are ultimately attributed to the perpetrators, though, Sri Lanka's postwar history makes it clear that the influence of radical Islamic organisations like ISIS can be at most a proximate cause. Such organisations may have influenced the choice of target and they may have even supplied material and technical resources, but such ideologies can only be appealing-even if only to a very small minority of Muslims-if they address deep and systematic wounds that already exist.

\section{MUSLIM RETURNEES IN JAFFNA}

Since 2010, Muslims have started to return to Jaffna, although, there have been no concrete programme from the successive post-war governments (Yusoff et al., 2018). The displaced Muslims, again and again, have voiced their grave concerns and wanted the government to facilitate their return and resettlement in their former areas, yet their case remains "a story of failure" that undermined international recognition and sustainability of Sri Lanka's post-war resettlement (Yusoff et al., 2018: p. 2). Thiranagama's prediction that large numbers of Muslims would return to their homes "with a new collective identity born through displacement" (Thiranagama, 2011: p. 167) did not hold true for the returnees, at least to those interviewed by the author. Though it is true that with displacement, identity, traditions and culture have been transformed (see also Malkki, 1995: p. 508), return also challenges Muslims more individually than collectively; their homes had either become ruins or were occupied by displaced Tamils, old jobs and livelihoods had seen decades of disruption, and schools were hardly functional.

It is being estimated that the current Muslim population in the entire Northern Province is around 250,000. However, only less than 30 percent have returned to their homes (Yusoff et al., 2018: p. 9). Around 1,990 displaced families are living in Puttalam, Colombo, Gampaha and Panadura areas under very difficult circumstances, while 700 other families have returned to Jaffna-though not in their own original homes, but nearby in Jaffna (Daily
FT , 2019). Among these 700 families, the Resettlement Ministry has promised to give around 365 families "better housing", but the remaining 335 families are still struggling (Daily FT, 2019). Most of the returnees were located at refugee camps in Puttalam, where they were compelled to live in abject conditions without being granted official refugee status. The few who returned between 2002 and 2006 were not provided with enough basic amenities by the government for their resettlement, particularly permanent housing and livelihood assistance. They laid claim to their properties that, in the interim, have been occupied by other displaced people. Further suffering occurred due to resource shortages and lack of support structures. This situation induced many to return to their displaced locales in Puttalam. The repeated pleas of the Muslim community to the authorities for enhanced security and protection have fallen on deaf ears even with the presence of Muslim ministers and members of parliament in the government (Yusoff et al., 2018). Therefore, this study will take a deeper look into the subjectivities of returnees to provide a comprehensive and in-depth example of how returnees negotiate the reconstruction of their lives in Jaffna. While the depth of the sense of disappointment is shared by the respondents, the ways in which they have reacted, reconsidered their subjective feelings of attachment to place, and the strategies they have developed are quite diverse. Although intensive agriculture, fishing and associated employment opportunities have a long history in Puttalam due to the fertility of the land and its proximity to the sea, the mistreatment and discrimination IDPs faced there outweighed these advantages - the desire to get rid of their 'refugee status' was rendered the highest priority.

The post-war period has witnessed several largescale developmental initiatives in the Northern Province which included programs to resettle IDPs. However, most of the programs were concerned with the Tamils, not the Muslims. As Asees (2015) pointed out, the end of the civil war brought hope for the resettlement of the Muslims, but the Sri Lankan government and the international community prioritised the Tamils. Except for the World Bank-funded Puttalam Housing Project, assistance in resettling the displaced northern Muslims has been very little.

The resettlement of evicted Muslims in Jaffna district became a serious challenge. Government authorities provided scant support for the returnees. They lack the most basic infrastructure, such as water supply and drainage systems. Yet, thousands of Muslims (the authors talked to around 30 of them in Jaffna) returned to their places of origin knowing that their homes no longer 
exist. All the respondents returned immediately with the end of the war in the year 2010 and since then are staying in Jaffna in rented places mostly but nearby to their original homes. Some of them have started rebuilding their old homes and others are saving money to do so. Their decisions to return are being related to a sense of attachment to their places of origin through memories. Besides, their aspirations of a better life also led them to return to Jaffna because they believe that Puttalam lacks various kinds of opportunities and services such as medical facilities, higher education facilities and entertainment. The respondents are convinced that return to Jaffna would also provide an end to the feelings of uncertainty, insecurity and fear with which they had been living with since displacement.

Anticipating their return to be a pleasant experience, as one might be indulged when returning to the family 'home', many respondents expressed their disappointment over how difficult their new life was. Despite the joy and happiness which marked the moment of their return, many described that they were upset about the demographic and socio-cultural changes which had occurred in their places of origin in Moor Street, during their forced displacement-a pattern which is quite common among displaced persons who return after a lengthy period, including Tamils who sought refuge abroad (McDowell, 1996; Fuglerud, 2001; Gerharz, 2010; 2014; Amarasingam, 2015). Adding to the general feeling of alienation, many expressed that they faced difficulties in regaining their land and rebuilding their damaged houses, properties and other basic facilities such as rehabilitation of divisional secretary offices, hospitals, maternity homes, schools, cooperative outlets, agrarian service centers and post offices, restoration of clean and safe drinking water and cleaning and construction of new wells.

Ten of the respondents expressed their frustrations about the prioritisation of the Tamil resettlement since the end of the war and it was only after 2013 that the resettlement programme for the Muslims began. They further stated that thousands of Muslims are still to be resettled in their former homes. The lack of Tamils' support for the return and resettlement of northern Muslims shows the existence of mistrust and antagonism between the two ethnic groups. Neither the local nor the national government offer land to returning Muslims for purchase and development. In addition, they did not receive the rations ${ }^{3}$ that repatriates were usually awarded due to their registrations not being finalised by the government agent ${ }^{4}$.

Each respondent is concerned about the thousands of fellow Muslims as they are now facing significant oppositions and challenges in promoting their ethnicity and in engaging in their religious and cultural practices. Serious problems also exist in resettling in their birthplaces and reclaiming ownership of their lands and properties. They are landless in certain villages because portions of land that belonged to Muslims were taken over by the army and navy for security reasons. In certain villages, displaced Tamils have already been resettled in lands that used to belong to them. After their eviction, their lands, houses and other buildings were destroyed, and those lands became overgrown with shrubs, trees and secondary forest, leaving no evidence of any previous human habitation. When they tried to acquire the deeds to their lands and settle there, they faced difficulties from local bureaucrats, the public and politicians. Respondents also stated that not only they, but those who returned to Mannar district faced similar kinds of problems with Tamil returnees over issues of land, the destruction of their homes, livelihood and income generation. They even complained that government and humanitarian actors, who are largely staffed by Tamils, were not sensitive to their needs and were unwilling to assist them. Thus, they experienced delayed resettlement for many months as authorities refused to provide clearance certificates and identified government lands.

Yet, they highlight the notion of attachment to their homes even after being away for more than two decades. They believe that home is linked to important life stages like childhood, adolescence and parenthood, and expressed in terms of experience and memories. Prior to displacement, they spent almost 30 years amidst their own environment and people. This long duration of stay created a very strong attachment to their neighborhood. This feeling of being 'at home' in Jaffna also developed as a connection to their past life. On one hand, memories of the childhood home are ingrained with fuzzy feelings of security, comfort and fixations of happiness (Bachelard, 1994), while on the other hand, traumatic events like war and displacement penetrate the dreams of childhood home. Thus, their idea of home is centered around Jaffna which has been viewed "as an ideal home" while simultaneously "a place of violence and pain" (Boer, 2015: p. 494). Respondents, similar to the view of Sumathy et al. (2009), described their past as one characterised by peacefulness, stability, a place where their family fitted in perfectly and did not face any obstacles regarding their culture and identity. After their return in 2010, many of them started rebuilding their homes, trying to retain the original structure of the old homes, highlighting the significance of the structure of the old house which seems to be of utmost importance and emphasising the desire to reconstruct what has been lost. When they moved to their newly built homes, they started having the same comfort 
as there used to be previously. Attachment to home is depicted through memories which is evident from one of the respondent's statements:

"Jaffna, being the source of good life, provoked us to return. Two important things that made 'me' to return was the sweet taste of water from the well and the few neighbors [...]."

The taste of the water in Jaffna is a common feature quoted by Tamil and Muslim people which entails enormous symbolic power. The sweet water represents home which is a symbol of nurturing energies for the family. Thus, attachment to home through these memories makes one "belong to spaces and sites, to natural objects, landscapes, climate, and to material possessions" as put by Pfaff-Czarnecka (2013: p. 17) in her article while explaining attachment; home is recognised as "a longing for a nostalgic past" (Al-Ali \& Koser, 2002: p. 7). Respondents romanticised memories by emphasising local traditions and social practices of the past days. They concentrated on their neighborhoods where they socialised during their childhood days. This is one of the main reasons for their return. They used to feel rooted in the geographical location and their relationships to their neighbors were constitutive of this.

However, "after return, we are disappointed!"; the actual experiences of return failed to meet their expectations. They were disappointed to see the dramatic transformations within their culture and among their community. The demographic composition of their locality, which used to be Muslims only, now consists of both Hindu and Christian Tamils which often leads to communal tensions. Upon their arrival, they were disheartened to observe the visible changes that had taken place, and which made the area 'unrecognisable': most of the houses are abandoned and falling, trees have grown wild around them, fields are overgrown and the old mosques have all been demolished. Their narrations reveal that return is inevitably nostalgic and about returning to memories, which contrasts to the present social structure of the multicultural neighborhood as it is now. In their memories, Moor Street in Jaffna was inhabited only by Muslims. Though they have succeeded in developing a relationship with their new neighbours, the kind of affinity that they used to have towards their previous neighbours is still missing. The relationships had changed over time-magnified in the imagination and unmatched by the experience of return. All of them were disappointed that relationships were "not what they used to be. There is a huge gap to fill on both sides. We pretend to know each other, but we don't'. Respondents were even worried about holding a conversation with them as they have hardly any idea from where to start and what to talk about. The discrepancy between past and present was shown by an uneasiness about not knowing how to act and react. A high level of self-awareness was displayed which also took a great deal of care in the actions towards others. Their return was in a sense a meeting of past and present, of imaginations and reality. All these respondents feel the difference of living in postwar Jaffna as opposed to the pre-war days. Familiar places have become unfamiliar. Yet they claim: “.... still Jaffna is home." They have faith in God and believe that they can soon get back to a good life. They carefully balance the need for economic security and emotional attachment to home. This attachment goes far beyond their house and extends to the entire neighborhood. They feel obliged to fulfill the "duties towards their lands and towards their mosques". Despite their dire living conditions at present in Jaffna, they consider it to be favorable compared to the "awful" years of displacement in Puttalam. "No place other than Jaffna could tempt" is the common statement among all the respondents with whom the authors met during their Jaffna visit. They are literally happy to return. To put in their voices, "...This is mine! This is where I belong! This is where I want to be!"

Therefore, the authors argue that the intimate connection between the respondents and their homes became obvious only when they experienced displacement, and the sufferings caused by displacement, and from the mere idea of losing their ownership of their home in Moor Street. In this context, Relph's (1976) statement fits perfectly:

"In our everyday life we may be largely unaware of the existence of such a bond and that the associations and commitments that do exist between people and their homes may become apparent only in time of loss and hardship" (p. 40).

This also proves the strong sense of attachment towards the ownership of their homes. For them, alienation from places of origin does not question their deep sense of belonging. Despite the initial feelings of ambivalence, they are confident that their dreams will become reality; patience and hard work will help them to regain the status-quo ante.

While explaining their situation in Puttalam, returnees highlighted that whatever they previously did seemed fake. One of the women respondents even told,

"Returning to Jaffna gave my identity back. I love to be here, I grew up here, Jaffna gave me everything. I feel like belonging to this place". 
Jaffna presents itself as a choice, a desire or an identity. It centers on a community and a society. She has been raised up in the town which provided her with physical comfort and with a sense of connection and belonging, not only to her family and household but also with her friends and neighbors. In Puttalam, she never felt like she belonged to anything. However, her return to Jaffna has not fulfilled her wish of staying at her own home, as it does not exist anymore. Since her return, she has been staying in a rented place which is nearby to her place of origin. Further, her current location does not deliver the same kind of feeling that she used to have in her 'own home'. Most of her old relations have either integrated into Puttalam or have moved to some other place in the country. She is left alone at her new locale in Jaffna. She believes that home is not only about a place but also about the people through whom she feels 'athome'. These experiences generate within her a constant shift in her understanding of 'home' and 'homeliness'. Thus, the idea of being 'homeless at home' evokes certain emotions like despair, isolation, grief and hopelessness. The new location has turned into an estrangement, as she neither knows her neighbors nor is she acquainted with the place. Her rented place fails to provide the material and immaterial comforts that she expects from her own home. In addition, she cannot live freely and independently because she must follow certain rules and limitations prescribed by the owner of the house. She is not even interested in making her new place like her own old home as she expects to rebuild her own home on her own land in the nearby future. She lacks enough income to buy land which she can claim to be her own, where she will have no limitations and can do whatever she feels like. Home is a combination of a place and a feeling where the 'person-environment' relationship creates feelings of well-being (Watkins \& Hosier, 2005: p. 198). To make things acceptable, adjustment is required to the new relationship between the person and the place. When this adjustment fails, people start feeling homeless. To her, the definition of home is rooted in physical comfort and in the personal history which has developed out of cumulative experiences through life and enduring memories. She used the space at her owned home, as she wished, which is not possible now. She felt the loss of emotional privacy at her new domain. Though she is not technically homeless, yet she feels that she has been without a 'true home' since she was forced to leave Jaffna in the 1990s. Thus, her narrative reflects the attachment to her home which compelled her to return despite all the uncertainties. In addition, her narrative also presents a picture of the difference between 'owning a house and renting a house'. Though she is staying near to her place of origin, she still cannot make it as her home because it fails to provide her physical comfort and privacy, which according to her, are the most important components in making a home.

A deep sense of disappointment exists over the rational considerations concerning job opportunities and future perspectives which urges fifteen of the middle-aged group respondents to consider alternative options: "We have to survive, no? In Jaffna, it is very difficult to get a job these days. So, moving to Colombo will be a good option".

Being disappointed with return, these respondents began to consider moving out from Jaffna to Colombo. Being graduates, they cannot find suitable jobs in Jaffna due to the high rate of unemployment. They are trying to balance the fond memories of past with future aspirations and the desire to achieve a 'good life'. Currently, being in-between the different priorities, their life urges them to make a decision between staying at the place called 'home' and emigrating to Colombo, where job opportunities are far better. The feeling of alienation from Jaffna, considering the absence of relatives and familiar neighbours relates to the "antagonistic sense of home", which Boer (2015: p. 493) reflects on in her article on Congolese refugees in Kampala. The lack of future perspectives and opportunities has become a decisive consideration for many young people in Jaffna, who tend to opt for leaving the peninsula to move to either Colombo or go abroad, where they hope to have better opportunities. The establishment and maintenance of transnational social spaces have become the norm in Jaffna, and migration serves as a strategy to reproduce social status within the locality, through individual and collective efforts (Gerharz, 2014).

Although the Government of Sri Lanka has been quick to promote peace-building reconciliation, this has not led to the demilitarisation of the region which also influences individual's strategic choices, as pointed out by one of the respondents:

"Jaffna is still indirectly under the control of the army. Here, the governing council is a retired major general of the Sri Lankan Army. Likewise, many important positions are under the military, which keeps Jaffna indirectly under militarisation".

Concerns about the militarisation of Jaffna resemble a discussion which has continued since the end of the war (Wickramasinghe, 2009; Höglund \& Orjuela, 2011; Thiranagama, 2013). Data collected in March 2015 also confirm the omnipresence of the Sri Lankan military all over the north: this not only prevents potential terrorists 
from reestablishing themselves, but also gives many residents feelings of being dominated and oppressed. In short, what has been sold as counter-terrorism measures by the government (Sentas, 2012: p. 109), constantly reminds the residents of the north of having been defeated and of having lost the dreams of freedom and self-determination which they might have aspired to throughout the war. With the force of the LTTE now absent, the true meaning of those notions emerges: freedom and self-determination is not only about finding a satisfactory political arrangement but touches upon individual's dignity and their dreams of a 'better life'.

\section{DIFFERENT KINDS OF ATTACHMENT}

The war in Sri Lanka caused large-scale displacements, and the almost complete eviction of the Muslim population from the Jaffna Peninsula by the LTTE has certainly contributed to the conflict dynamics. The suffering of this population has been immense, and while this exodus has hardly been dealt with appropriately since the signing of the Ceasefire Agreement, it has certainly deepened cleavages between Tamil and Muslim protagonists. Though the end of the war created high hopes among the displaced northern Muslims that their lives as refugees would end, post-war development and resettlement initiatives poorly accommodated the concerns and grievances of these forcefully evicted populations and their permanent resettlement in their own homes. Secondary data gathered during fieldwork show that the Sri Lankan government and international actors mostly prioritised the displaced Tamils and sidetracked the resettlement of the Muslims from the north. The few initiatives for the resettlement of these Muslims faced serious challenges and opposition from extreme nationalists representing Sinhalese-Buddhist and political forces among Tamils. The Muslims had been living with the Tamils in the northern province for centuries and returning to their homeland is their right that must be accepted and fulfilled by government authorities and concerned parties in the post-war development and resettlement processes. Government authorities as well as commissions and international organisations have promised the permanent resettlement of the northern Muslims. However, no meaningful initiatives have been, yet, undertaken for ensuring the permanent resettlement of the Muslims.

Nevertheless, feelings of attachment prevail among the Muslims although the evictions forced an alienation to their home in Jaffna. The analysis unveils different kinds of attachments to home through memories, emotions and, material and immaterial property. An important dimension is the emotional and spiritual attachment to the original home. It is through the soil, air and water which individuals relate themselves to their homes. Another important reason for their return is regaining lost social status. Longing for return lingered as an important step, especially among those who were not able to climb the social ladder in other parts of the country. A return to Jaffna promised at least being at ease with an individual's emotional relationship to a place that is deeply ingrained in their memory.

Thiranagama (2011: p.130) suggests, with respect to the return of minority populations to their homes,

"that the relationship of the two, what was once home is not just one about relationships to the past, but about the possibilities of belonging in the future, the possibilities of finding a future in which one can flourish personally and collectively".

This suggestion can be seen in the responses of the respondents, who described their attachment to their home as being connected to both their romanticised past and the future in which they aspire to establish themselves. Even though the search for economic security may force them to leave Jaffna again, 'home' continues to offer the memories of former social, emotional and spiritual sustenance, memories which will continue to shape their belonging in the future.

However, there is also a strong sense of disappointment with the experience of return which challenges the various dimensions of attachment. The place and the people living there have been transformed in many ways. Safety and security issues are at stake. Sinhalese nationalism together with the ardent militarisation of the northeast continues to infiltrate the daily lives of Muslims, as shown by Hyndmann \& Amarasingam (2014: p. 573) in their study. Familiar places have become unfamiliar. The fond memories of these places have transformed into broken ones. The physical environment surrounding people's homes has deteriorated after the war. Most of the houses are either abandoned or falling, trees have grown all around them, fields are overgrown and the old mosques have been demolished. It's not only the physical environment that has changed, but their treasured culture and social relationships as well. There is much reminiscing about the good old days spent with family, relatives and friends, because almost all of them have either emigrated or died due to the war, thereby creating a social vacuum in their neighborhoods.

Because of the hardships they are experiencing since the return, returnees share feelings of alienation and detachment that are more fundamental than those 
produced by cultural differences. Their aspirations for a good life also seem to be decaying along with their homes. Because they have witnessed war so closely, fear and trauma associated with the presence of military prevails. The attachment towards home becomes overshadowed with a detachment. Furthermore, with the Easter Sunday bombings, things have changed drastically for the Muslims, especially the ban on burqas. One of the respondents, who is a female activist, explained that many school-going girls and university students choose to wear burqas,

"because sometimes this is the only way to access education and higher education for some Muslim women. For some women, wearing the burqa is an important signifier for them of their identity, and they have also used this to overcome oppression, contrary to popular belief, and have as a result furthered their achievements in many fields".

She further spoke about her concerns for this ban as she believes that this will "push these women - many of whom are already in a process of fighting or striving to gain their rights-further into the margins". It would be painful and difficult for them to show their faces in public when they have been living for decades wearing the face cover and being taught to believe that they are sinners if they do not do so. Through this ban, these women are going to lose their freedom and this will affect the ordinary Muslim women in their daily lives. Banning the burqa may result in girls having to give up schools, universities and social service activities; "This will definitely affect the development of half of our women and the entire Muslim community in the long run". Therefore, several Muslim women have been already denied entry into many places, including hospitals and schools.

In his book, In Search of Politics, Zygmunt Bauman uses the German term Unsicherheit to denote three dimensions, i.e. insecurity, uncertainty and an unsafe environment. Insecurity, according to Bauman, is viewed as losing a possession which has been won and gained, while uncertainty is staying unaware of the differences between proper and improper, useful and useless, trustworthy and treacherous, and things which are experienced in day-to-day life. The third dimension, unsafe refers to a threat to one's body, property or environment. All these dimensions are conditions of one's own self which results in a disappearance of self-assurance, a loss of trust in oneself, growing anxiety, fault-seeking and fault-finding, aggression and scapegoating (Bauman, 1999: p. 17).

An intensified version of Unsicherheit can been found in Jaffna, where the fear of living under political control and enduring continuing militarisation has become a daily routine for the population even after a decade since the war ended. Jaffna has become an insecure place as almost everybody has lost their material and immaterial belongings due to displacement. The few things that they have achieved or regained after the war could be lost again any moment. They still have the fear that at any time they could be again asked to leave their possessions and move away. Due to the lack of employment opportunities, their future remains uncertain. Therefore, this article leaves room for future studies which can focus on the recent developments of the livelihoods of the Muslim returnees after almost a decade of the end of the war-if they have succeeded in establishing their dreams or still seeking for a good life.

\section{END NOTES}

1. Madrasa are a specific type of religious schools or colleges for the study of the Islamic religion but not limited to it.

2. The NTJ is a small radical Muslim group in Sri Lanka which has no history of mass fatal attacks but came to prominence last year linked to the vandalism and desecration of Buddhist statues.

3. Rations include rice, pulses, biscuits, canned food, cereals, sugar and kerosene.

4. Final report (2012) of the Citizens' Commission on the Expulsion of the Muslims from the Northern Province by the LTTE in October 1990.

\section{REFERENCES}

Ainsworth, M. S. (1979) Infant-Mother Attachment, American Psychologist, 34(10), pp: 932-937.

DOI: https://doi.org/10.1037//0003-066x.34.10.932

Arudpragasam, A. (2019) A State of Disorientation: Dispatch from Sri Lanka after the Easter Bombings, TIME, $22^{\text {nd }}$ May [Online] Available from: https://time.com/5593101/dispatchsri-lanka-easter-bombings/ [Accessed: $10^{\text {th }}$ June 2019].

Al-Ali, N. and Khalid, K. (2002) New Approaches to Migration: Transnationalism and Transformations of Home, London: Routledge.

Amarasingam, A. (2015) Pain, Pride, and Politics: Sri Lankan Tamil Activism in Canada, Athens: University of Georgia Press.

Appadurai, A. (1986) The Social Life of Things: Commodities and the Politics of Value, Cambridge: Cambridge University Press. 
Appadurai, A. (2004) The Capacity to Aspire, In: Rao. V, \& Walton, P. A. (eds) Culture and Public Action, pp: 59-84, Stanford University Press.

Asees, M. S. (2015) Resettlement of northern Muslim IDPs: A case study of Marichukkati village in Mannar district of Sri Lanka, In: University of Colombo, Annual Research Symposium, Colombo: Sri Lanka, October 2015 [Online] Available from: http://archive.cmb.ac.lk:8080/research/ bitstream/70130/4180/1/M.S.Asees-017.pdf [Accessed: 30 ${ }^{\text {th }}$ November 2018].

Bachelard, G. and Maria, J. (1994) The Poetics of Space, New York: Penguin Books.

Bauman, Z. (1999) In Search of Politics, Cambridge: Polity.

Boer, R. D. (2015) Liminal Space in Protracted Exile: The meaning of Place in Congolese Refugees' Narratives of Home and Belonging in Kampala, Journal of Refugee Studies, 28(4), pp: 486-504.

DOI: https://doi.org/10.1093/jrs/feu047

Bowlby, J. (1998) Attachment and Loss, New York: Basic Books.

Chattoraj, D. (2017) Ambivalent attachments: shifting notions of home among displaced Sri Lankan Tamils, Ph. D., RuhrUniversität Bochum: Germany [Online] Available from: https:// hss-opus.ub.ruhr-uni-bochum.de/opus4/frontdoor/deliver/ index/docId/5453/file/diss.pdf [Accessed: 30 ${ }^{\text {th }}$ November 2018].

Chattoraj, D. (2018) Experiences of Sri Lankan Tamils Displaced to Colombo: Three Narratives, eTropic: Electronic Journal of Studies in the Tropics, 17(1), pp: 137-148.

DOI: https://doi.org/10.25120/etropic.17.1.2018.3646

Chattoraj, D. (2019) Narratives of Sri Lankan Displaced Tamils Living in Welfare Centres in Jaffna, Sri Lanka, Journal of Maritime Studies and National Integration, 2(2), pp: 67-74.

DOI: https://doi.org/10.14710/jmsni.v2i2.3707

Chattoraj, D. and Gerharz, E. (2019) Difficult Return: Muslims' Ambivalent Attachments to Jaffna in Post-Conflict Sri Lanka, Working Paper Series 46, Institute of Asian Studies, Universiti Brueni Darussalam: Gadong, Brunei.

Cheran, R. (2000) Changing Formations: Tamil Nationalism and National Liberation in Sri Lanka and the Diaspora, Ph. D. (unpublished), York University: Toronto.

Cheran, R. (2007) Transnationalism, development and social capital: Tamil community networks in Canada, In Goldring., L. \& Krishnamurti, S.(eds) Organizing the Transnational: Labour, Politics and Social Change, pp: 129-144 [Online] Available from: https://www.ubcpress.ca/asset/9564/1/9780774814072. pdf [Accessed: $30^{\text {th }}$ November 2018].
Cresswell, J. W. (2003) Research Design: Qualitative, Quantitative and Mixed Methods Approaches, Sage Publications.

Daily FT (2019) Displaced Jaffna Muslims Hear Good News After Three Decades, Daily FT [Online] 19 $9^{\text {th }}$ February, Available from: http://www.ft.lk/NEWS/DISPLACEDJAFFNA-MUSLIMS-HEAR-GOOD-NEWS-AFTERTHREE-DECADES/56-673111 [Accessed: 20 $0^{\text {th }}$ April 2019].

Fonseka, B. and Raheem, M. (2011) Land issues in the Northern Province: Post War Politics, Policy, and Practices, Colombo: Centre for Policy Alternatives.

Fuglerud, Ø. (2001) Time and space in the Sri Lanka-Tamil diaspora. Nations and Nationalism, 7(2), pp: 195-213.

DOI: https://doi.org/10.1111/1469-8219.00012

Gerharz, E. (2010) When Migrants Travel Back Home: Changing Identities in Northern Sri Lanka after the Ceasefire of 2002, Mobilities, 5(1), pp: 147-165.

DOI: https://doi.org/10.1080/17450100903435060

Gerharz, E. (2014) The Politics of Reconstruction and Development in Sri Lanka: Transnational Commitments to Social Change, New York: Routledge.

DOI: https://doi.org/10.4324/9781315777214

Hammond, L. (1999) Examining the discourse of repatriation: towards a more proactive theory of return migration, In: Richard, B. and Khalid, K. (eds) The end of the refugee cycle/: Refugee, Repatriation and Reconstruction, pp: 227-244, New York: Berghahn Books.

Haniffa, F. (2014) Competing for victimhood status: Northern Muslims and the ironies of post-war reconciliation, justice and development, ICES Research Papers [Online] Available from: https://www.academia.edu/9968354/Competing_for Victimhood_Status_Northern_Muslims_and_the_Ironies_ of_Postwar_Reconciliation_Justice_and_Development [Accessed: $30^{\text {th }}$ November 2018$]$.

DOI: https://doi.org/10.5334/sta.fj

Haniffa, F. (2007) Muslims in Sri Lanka's Ethnic Conflict, ISIM Review, 19(1), pp: 52-53.

Hasanah, C. I. (2019) In the name of security: How the Burqa/ Niqab Ban is Impacting Muslim Women, Groundviews, $22^{\text {nd }}$ May [Online] Available from: https://groundviews. org/2019/05/22/in-the-name-of-security-how-the-burqa-niqabban-is-impacting-muslim-women/ [Accessed: $10^{\text {th }}$ June 2019].

Hasbullah, S. and Benedikt, K. (2013) Muslim Geographies, Violence and the Antinomies of Community in Eastern Sri Lanka, The Geographical Journal, 179(1), pp: 32-43.

DOI: https://doi.org/10.1111/j.1475-4959.2012.00470.x

Hasbullah, S. H. (2004) Justice for the dispossessed: The case of a forgotten minority in Sri Lanka's ethnic conflict, Sri Lankan 
society in an era of globalization: Struggling to create a new social order, pp: 221-240, Colombo: Vijitha Yapa publications, Colombo.

Höglund, K. and Orjuela, C. (2011) Winning the Peace: Conflict Prevention after a Victor's Peace in Sri Lanka, Contemporary Social Science, 6(1), pp: 19-37.

DOI: https://doi.org/10.1080/17450144.2010.534491

Hooks, B. (2009) Belonging: A Culture of Place, New York: Routledge.

Hyndman, J. and Amarasingam, A. (2014) Touring Terrorism: Landscapes of Memory in Post-War Sri Lanka, Geography Compass, 8(8), pp: 560-575.

DOI: https://doi.org/10.1111/gec3.12149

IRIN News (2013) Sri Lanka's Muslim IDPs 25 years on [Online] Available from: http://www.thenewhumanitarian. org/analysis/2013/01/21/sri-lanka-s-muslim-idps-25-years [Accessed: 10 $0^{\text {th }}$ June 2019].

Ismail, M. and Azeez, A. (2014) One Distinguished Family of Moor Street Jaffna, Dehiwala, Sri Lanka: Dr. A.M.A. Foundation.

Jeyaraj, D. B. S. (2015) LTTE's Cruel Conduct on Tamil Civilians in Wanni, Daily Mirror [Online] 25th September, Available from: http://www.dailymirror.lk/88895/ltte-s-cruelconduct-on-tamil-civilians-in-wanni [Accessed: 10 $0^{\text {th }}$ June 2019].

Kadirgamar, A. (2015) The other Oppressed Minority, The $H i n d u$ [Online] 26 ${ }^{\text {th }}$ October, Available from: https://www. thehindu.com/opinion/lead/The-other-oppressed-minority/ article10176292.ece [Accessed: $30^{\text {th }}$ November 2018].

Kvale, S. (1996) Interviews: An Introduction to Qualitative Research Interviewing, California: Sage.

Malkki, L. H. (1995) Refugees and Exile: From "Refugee Studies" to the National Order of Things, Annual Review of Anthropology, 24(01), pp: 495-523.

DOI: https://doi.org/10.1146/annurev.anthro.24.1.493

McDowell, C. (1996) A Tamil Asylum Diaspora: Sri Lankan Migration, Settlement and Politics in Switzerland. Vol. 1, New York, Oxford: Berghahn Books.

DOI: https://doi.org/10.2307/3034884

McGilvray, D. B. (1998) Arabs, Moors and Muslims: Sri Lankan Muslim Ethnicity in Regional Perspective, Contributions to Indian Sociology, 32(2), pp: 433-483.

DOI: https://doi.org/10.1177/006996679803200213

Minority Voices Newsroom (2014) Sri Lanka: The forgotten people: 24 years of forcible eviction of Northern Muslims [Online] Available from: http://www.minorityvoices.org/ news.php/en/1736/sri-lanka-the-forgotten-people-24-years- of-forcible-eviction-of-northern-muslims (Accessed: $10^{\text {th }}$ June 2019).

Pfaff-Czarnecka, J. and Toffin, G. (2011) Introduction: Belonging and Multiple Attachments in Contemporary Himalayan Societies, In: Pfaff-Czarnecka, J. and Toffin, G. (eds) The Politics of Belonging in the Himalayas: Local Attachments and Boundary Dynamics, pp: 11-38, New Delhi, Sage.

DOI: https://doi.org/10.4135/9788132107729

Pfaff-Czarnecka, J. (2013) Multiple Belonging and The Challenges to Biographic Navigation, $M M G$ Working Article, 13(5), Göttingen: Max-Planck-Institut zur Erforschung multireligiöser und multiethnischer Gesellschaften.

Relph, E. (1976) Place and Placeness, Vol. 1, Pion (California: Sage).

Sanathanan, T. (2011) The Incomplete Thombu, Colombo: Raking Leaves.

Sentas, V. (2012) One More Successful War? Tamil Diaspora and Counter-Terrorism after the LTTE, In: Poynting, S. and Whyte, D. (eds) Counter-Terrorism and State Political Violence: The 'War on Terror' as Terror, pp: 97-115, London and New York: Routledge.

DOI: https://doi.org/10.4324/9780203116333

Sri Lanka, Report of the Commission of Inquiry on Lessons Learnt and Reconciliation (2011) Report of the Commission of Inquiry on Lessons Learnt and Reconciliation [Online] Available from: http://slembassyusa.org/downloads/LLRCREPORT.pdf [Accessed: 10 $0^{\text {th }}$ June 2019].

Sumathy, S., Nazeera, Subaida, Latha, Kaushi, Nasrina, Felicia, Sharmila, Shiyana, Madeena Umma, Saseetha, Thahiya, Vasuki \& Juweriya (2009) Salt, sand and water: Movement and citizenship in the narratives of displaced women, Social Identities, 15(1), pp: 11-42.

DOI: https://doi.org/10.1080/13504630802692879

Thiranagama, S. (2011) In my Mother's House: Civil War in Sri Lanka, Philadelphia: University of Pennsylvania Press.

DOI: https://doi.org/10.9783/9780812205114

Thiranagama, S. (2013) Claiming the State: Postwar Reconciliation in Sri Lanka, Humanity: An International Journal of Human Rights, Humanitarianism and Development, 4(1), pp: 93-116.

DOI: https://doi.org/10.1353/hum.2013.0011

Van Hear, N. and Rajasingham-Senanayake, D. (2006) From Complex Displacement to Fragile Peace in Sri Lanka, In: van Hear, N. and McDowell, C. (eds) Catching Fire: Containing Forced Migration in a Volatile World, pp: 45-71, Lanham: Rowman \& Littlefield.

Watkins, J. F. \& Hosier, A. F. (2005) Conceptualizing home and homelessness: A life course perspective, In Rowles, G. 
D. \& Chaudhury, H. (eds) Home and identity in late life: International perspectives, pp: 197-215 [Online] Available from: https://books.google.lk/books?hl=en\&lr=\&id=peoUWT22124C\&oi $=$ fnd \&pg $=$ PR $5 \& d q=$ Home + and + identity+in+late+life:+International+perspectives\&ots=dcrgSqbMby\&sig=RYRZRy9ezDxNhZzuVhEqF7BWUNQ\&redir es$\mathrm{c}=\mathrm{y} \# \mathrm{v}=$ onepage $\& \mathrm{q}=$ Home $\% 20$ and $\% 20$ identity $\% 20 \mathrm{in} \% 20$ late $\% 201$ ife $\% 3 \mathrm{~A} \% 20$ International $\% 20$ perspectives $\& \mathrm{f}=$ false [Accessed: 10 $0^{\text {th }}$ June 2019].

Wickramasinghe, N. (2009) Sri Lanka in 2008: Waging War for Peace, Asian Survey, 49(1), pp: 59-65.

DOI: https://doi.org/10.1525/as.2009.49.1.59

Yusoff, M. A., Sarjoon, A. and Mohd Zain, Z. (2018) Resettlement of Northern Muslims: A Challenge for Sustainable
Post-War Development and Reconciliation in Sri Lanka, Social Sciences, 7(7), 106.

DOI: https://doi.org/10.3390/socsci7070106

Zetter, R. (1999) Reconceptualizing the myth of return: continuity and transition amongst the Greek-Cypriot refugees of 1974, Journal of Refugee studies, 12(1), pp: 1-22.

DOI: https://doi.org/10.1093/jrs/12.1.1

Žíla, O. (2015) The myth of return: Bosnian refugees and the perception of 〈home, Geographica Pannonica, 19(3), pp: 130145.

DOI: https://doi.org/10.5937/geopan1503130z 